Walt, J. P. van Der \& Tscheuschner, I. T. (1956). J. gen. Microbiol. 14, 485-486

\title{
Saccharomyces pretoriensis n.sp.-from South African Soil
}

\author{
By J. P. VAN DER WALT aNd IRMGARD T. TSCHEUSCHNER \\ National Chemical Research Laboratory, South African Council for Scientific and \\ Industrial Research, Pretoria, South Africa
}

SUMMARY: A new Saccharomyces species has been isolated from soil. It is distinguished from other species of the genus by its ability to ferment glucose, galactose, sucrose, maltose and raffinose $1 / 3$, as well as by its small cells and the formation of protuberances resembling conjugation tubes during sporulation.

In a recent survey of the yeast flora associated with surface soil, a round-celled sporogenous strain was isolated. Characteristic of the strain was the formation, during sporulation, of protuberances resembling conjugation tubes.

\section{METHODS AND RESULTS}

The following description is based on the standard procedures described by Lodder \& Kreger-van Rij (1952).

\section{Description}

Growth in malt extract. After 3 days at $25^{\circ}$ the cells are round $(2 \cdot 6-6 \cdot 3 \mu$.$) ,$ single or in pairs. After 1 month at $17^{\circ}$ a sediment is formed.

Growth on malt agar. After 3 days at $25^{\circ}$ the cells have the same shape and size as those in malt extract. After 1 month at $17^{\circ}$ the streak culture is soft, dull, glistening and smooth, brownish to cream-coloured. Margin smooth.

Slide cultures. No pseudomycelium is formed.

Sporulation was examined on malt agar and the common sporulation media. Isogamous or heterogamous conjugation may occur. Ascus formation without immediately preceding conjugation also occurs. Cells with protuberances are formed. Spores are round, usually with an internal oil drop. One to four spores are formed (PI. 1, fig. 1).

\begin{tabular}{|c|c|c|c|c|}
\hline Fermentation. & Glucose & + & Maltose & + \\
\hline & Galactose & (slow) & Lactose & - \\
\hline & Sucrose & + & Raffinose & $1 / 3$ \\
\hline Sugar assimilation. & Glucose & + & Maltose & + \\
\hline & Galactose & + & Lactose & - \\
\hline & Sucrose & + & & \\
\hline
\end{tabular}

Assimilation of potassium nitrate. Absent.

Ethanol as sole source of carbon. Growth.

Splitting of arbutin. Absent.

\section{DISCUSSION}

As the organism forms no pellicle, ferments glucose vigorously and cannot assimilate nitrate, it must be classified as a species of genus Saccharomyces (Meyen) Reess as diagnosed by Lodder \& Kreger-van Rij (1952). Bio- 
chemically, this strain shows great similarity to Saccharomyces cerevisiae in its fermentation of glucose, galactose, sucrose, maltose and raffinose for one-third. Morphologically the comparatively small round cells, the round spores with endogenous lipid globules, and especially the formation of protuberances, are again features which the strain from soil has in common with the group of Saccharomyces species formerly classified as Torulospora, viz. Saccharomyces delbrueckii, $S$. rosei and $S$. fermentati. The morphological resemblance to $S$. fermentati is particularly marked. Since mature cells of the strain from soil are considerably smaller than those of $S$. cerevisiae, it cannot be classified as this species. Similarly, it cannot be identified with either $S$. delbrueckii, S. rosei or $S$. fermentati, since none of these species ferments or even assimilates galactose. The organism must therefore be regarded as representing a new species. The name $\boldsymbol{S}$. pretoriensis is proposed for Pretoria where the yeast was isolated.

A subculture of $S$. pretoriensis has been deposited in the Yeast Collection of the Centraal Bureau voor Schimmelcultures in Delft.

\section{LATIN DIAGNOSIS}

Saccharomyces pretoriensis sp.nov.

In musto maltato cellulae rotundae $(2 \cdot 6-6 \cdot 3 \mu$.), singulae aut binae. Sedimentum formantur.

In agaro maltato cellulae formae et dimensiones cellularum eaedem sunt que in musto maltato.

Cultura (post unum mensem, $17^{\circ}$ ) mollis, parum nitens, glabra, albiflava. Margine glabro.

Pseudomycelium nullum.

Copulatio cellularum aequarum inaequarumque asci plerumque conformationi praecedit. Etiam asci conformationi sans copulatione praecedit. Cellulae cum tuberis similibus tubulis conjugationibus.

Ascosporae rotundae; globulos olei continent, 1-4 in asco.

Fermentatio glucosi, galactosi (lente) sacchari, maltosi et raffinosi pro tertia parte. In medio minerali cum glucoso, galactoso, saccharo et maltoso crescit. Nitras kalicus non assimilatur. In media minerali cum alcohole aethylico crescit. Arbutinum non finditur.

The authors' thanks are due to Professor A. Pijper for his kind assistance with the photography. This paper is published with the permission of the South African Council for Scientific and Industrial Research.

\section{REFERENCE}

Lodder, J. \& Kreger-van Riv, N. J. W. (1952). The Yeasts. A Taxonomic Study. Amsterdam: North Holland Publishing Co.

\section{EXPLANATION OF PLATE}

Fig. 1. Saccharomyces pretoriensis n.sp. Spores and protuberances in a sporulating culture. ( $\times 1000$; sunlight dark-ground microscopy.)

(Received 10 November 1955) 
Journal of General Microbiology, Vol. 14, No. 2

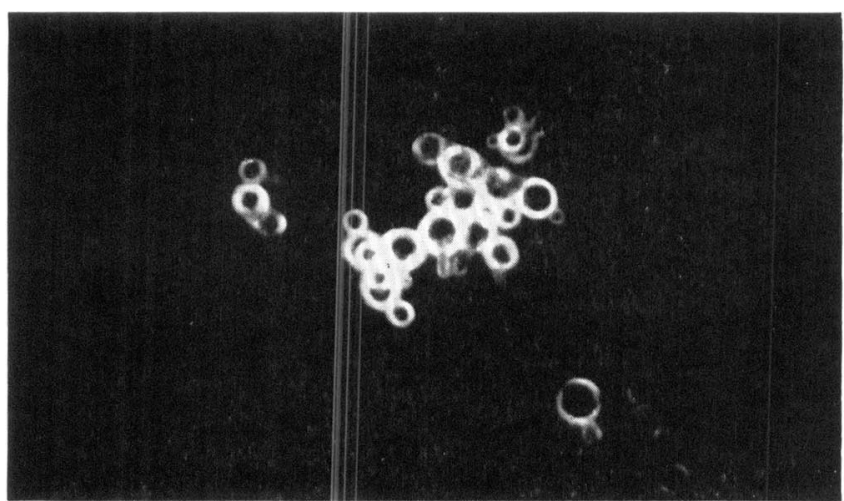

J. P. van mer WalT \& I. 'T. 'Tschuuschner-Saccharomyeles pretoriensis. PIATE 1 


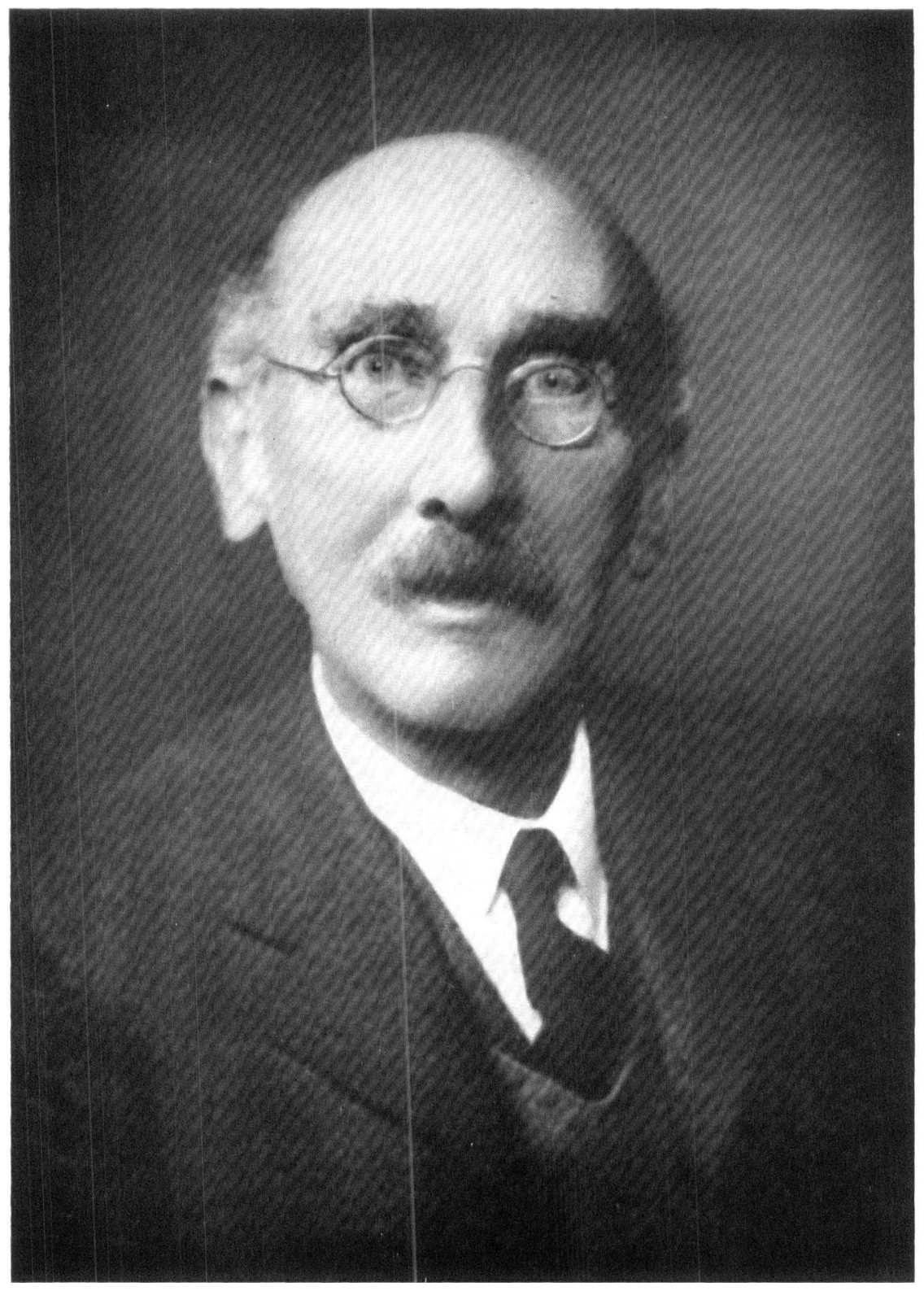

CHARLES JAMLS MARTIN 